\title{
A PRELIMINARY REPORT OF REPTILIAN MORTALITY ON ROAD DUE TO VEHICULAR MOVEMENTS NEAR KAZIRANGA NATIONAL PARK, ASSAM, INDIA
}

\author{
Abhijit Das', M. Firoz Ahmed², Bibhuti P. Lahkar and Pranjit Sharma \\ 1 2Division of Herpetology, Aaranyak, Sommonoy Path, Survey, Beltola, Guwahati, Assam 781028, India \\ 1Email: abhijitdas80@rediffmail.com
}

\section{Abstract}

We report road mortality of reptiles on a highway segment passing along the southern boundary of Kaziranga National Park, Assam, India. A total of 68 instances of road kills of reptiles belonging to 21 species and seven families were recorded. There was a greater mortality among snakes compared to lizards. The arboreal reptiles were the most affected, the highest percent being those that were diurnal followed by the nocturnal, crepuscular and both day and night active species. Possible explanations of such differences in mortality among reptile groups are discussed. It is feared that such kind of persistent loss can be detrimental to the local reptilian population.

KEYWORDS

Assam, India, Kaziranga National Park, reptile, road kill

Of late, roads have been recognized to produce various kinds of ecological consequences including habitat loss and fragmentation (Carr \& Fahrig, 2001; Reed et al., 1996; Vos \& Chardon, 1998). Roads have become one of the growing threat to animal and plant populations (Forman \& Alexander, 1998; Trombulak \& Frissell, 2000). Through direct mortality on the roads (Ashley \& Robinson, 1996), or indirect effects such as the modification of adjacent aquatic and terrestrial communities through vehicle exhaust or runoff (Turtle, 2000), or barriers for movement (Oxley et al., 1974), or increased predator activity near roads (Ortega \& Capen, 1999) roads contribute to reduced average heterozygosity and genetic polymorphism (Reh \& Seitz, 1990).

Roads appear to be barriers to movements for some birds and mammals (Develey \& Stouffer, 2001; Goosem, 2001) but not for others (Goosem, 2001; Mc Donald \& St. Clair, 2004). Studies dealing with mortality of relatively slow moving animals with limited dispersal ability, such as reptiles (Haxton, 2000; Rosen \& Lowe, 1994), and amphibians (Hels \& Buchwald, 2001) have been conducted elsewhere. Investigators have suggested that the growing intensity of traffic on roads at the global scale is a contributing factor to declining amphibian populations (Fahrig et al., 1995). Herpetofauna with less dispersal ability and greater sensitivity to habitat alteration than birds and mammals may be more sensitive to barrier effect of roads (deMaynadier \& Hunter, 2000) and local populations may become isolated and increasingly become susceptible to extinction (Mader, 1984).

In India few studies were carried out to address the issue of herpetofaunal mortality on roads (Vijaykumar et al., 2001, Gokula, 1997, Chhangani, 2004), but considering northeastern India, which is a diversity hotspot for herpetofauna (Jayaram, 1974), no study on such ecological loss is hitherto known.

\section{Study Area}

The study was carried out during May 2004 to September 2004 on a $60 \mathrm{~km}$ road segment of National Highway 37, passing adjacent to Kaziranga National Park $\left(26^{\circ} 34^{\prime}-26^{\circ} 46^{\prime} \mathrm{N} \& 93^{\circ} 08^{\prime}-\right.$ $\left.93^{\circ} 36^{\prime} \mathrm{E}\right)$ (KNP), Assam, India. The $7.5 \mathrm{~m}$ wide paved road separates the southern side of Kaziranga National Park from Karbi Anglong Hills (KAH) and passes through tea gardens, human habitations, paddy fields, teak plantations besides forest habitats of KNP at Panbari, Haldibari, Kanchanjuri and Ghorakati (Fig. 1). All these adjacent forest habitats are animal corridors and are frequently used by megamammals like Elephants, Indian One-horned Rhinoceros, Water Buffalo, Tiger, Leopard and Hog Deer during their to and fro movement between KNP and KAH.

The animal crossing increases manifold particularly during the rainy season (July-September) when the water from river Brahmaputra on the northern side inundates the low-lying areas of KNP.

\section{Methodology}

We followed the 'night driving method' to detect reptiles on the road. This method is a type of road transect that yields a reasonable estimate of the species and individuals actively foraging or migrating to and from breeding sites (Shaffer \& Juterbock, 1994). This technique outlined by Klauber (1939) has been used extensively to assess the relative abundance and species richness of reptiles (Dodd et al., 1989; Fitch, 1949; Rosen \& Lowe, 1994) and amphibians (Fahrig et al., 1995).

We conducted a $60 \mathrm{~km}$ road transect on $\mathrm{NH} 37$ from Burapahar range to Bokakhat town covering the entire southern length of the park. The transect was covered (Bokakhat as starting point and back) thrice every week between 0600-1000hr and 1800-2300hr. The vehicle was driven at $10-20 \mathrm{~km} / \mathrm{hr}$ depending on visibility, and any reptilian road kill seen was either collected as vouchers or removed from the road to avoid multiple counts and the roadside habitat, state of road kills and location of the road kills were recorded. We used taxonomic keys (Smith, 1935, 1943; Zhao \& Adler, 1993) for species identification. Scientific and common names of reptiles were after Das $(1997,2002,2003)$. A few species could be identified up to generic level only. Wherever possible, reptiles crossing the road were caught, identified and released off the road in the direction they were heading.

\section{Results}

Road kills of 68 individuals of reptiles belonging to 21 species and seven families were recorded. Among them $89.7 \%$ 


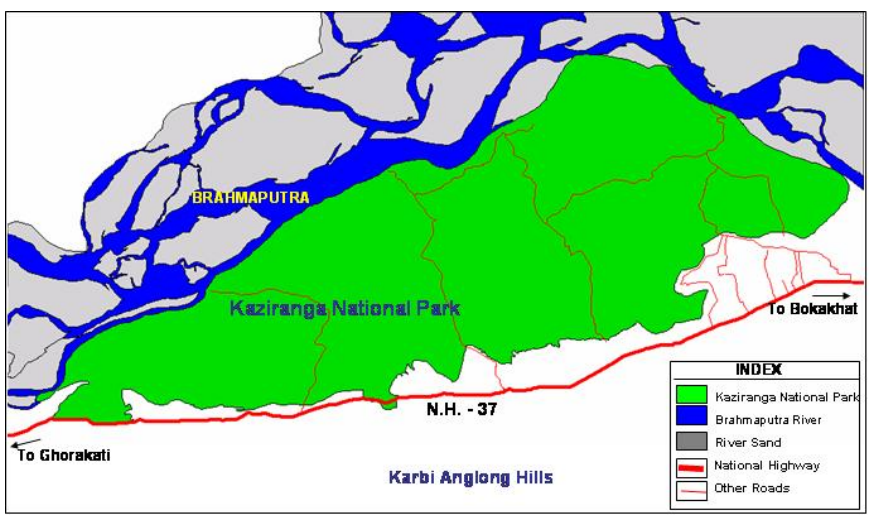

Figure 1. Kaziranga National Park and National Highway 37

$(n=61)$ were snakes followed by lizards $10.2 \%(n=7)$. No chelonian mortality was recorded.

Snakes belonging to the families Colubridae (13 species), Elapidae (2 species), Viperidae (1 species) and Boidae (1 species) were recorded, while lizards belonging to the families Scincidae (2 species), Gekkonidae (1 species) and Agamidae (1 species) were recorded (Table 1 ).

The individuals of the species Boiga gokool were more frequently encountered ( 14 dead; 5 alive) than individuals of any other reptile species.

The percentage of road mortality among arboreal reptiles (Boiga, Chrysopelia, Dendralaphis, Calotes, Trimeresurus, Gekko) was the highest $(42.6 \%(\mathrm{n}=29))$ followed by terrestrial reptiles (Amphiesma, Mabuya, Lygosoma, Bungarus, Coelognathus $36.7 \%$ $(\mathrm{n}=25)$ ), arboreo-terrestrial (Python, Lycodon, Ptyas, Ophiophagus $13.2 \%(\mathrm{n}=9))$ and aquatic species (Enhydris, Xenochrophis $7.3 \%$ $(\mathrm{n}=5))$.

Among the members of the day active species belonging to genera Calotes, Mabuya, Lygosoma, Amphiesma, Chrysopelia, Dendralaphis, Ptyas, Ophiophagus road mortality amounted to $38.2 \%(\mathrm{~N}=26)$, whereas road mortality among nocturnal (Gekko, Boiga, Lycodon, Bungurus, Trimeresurus), crepuscular (Python and Coelognathus) and both day-night active species (Enhydris, Xenochrophis) accounted for $36.7 \%(\mathrm{~N}=25), 17.6 \%$ $(\mathrm{N}=12), 7.3 \%(\mathrm{~N}=5)$ respectively.

A number of reptilian species were recorded either crossing the road or close to the road $(<5 \mathrm{ft}$ on road side habitat) (Table 2).

\section{Discussion}

Large representation of snakes as road-kill may be because (i) snakes use roads as substrate for thermoregulation; (ii) unlike lizards, their movements on a paved road is relatively slow; (iii) NH 37 represents only high land where snakes can take shelter during high flood; (iv) movement related to reproductive behaviour, as during our study period, we recorded road mortality of gravid individuals of Boiga gookol $(\mathrm{n}=4)$, Amphiesma stolata $(\mathrm{n}=2)$ and Chrysopelia ornata $(\mathrm{n}=1)$.

Such kind of persistent loss at population level may be detrimental for the species as road mortality of snakes has been identified as constituting a 'sink' for local populations (Rosen \& Lowe, 1994).
Table 1. List of reptilian fauna found dead on road run over by vehicles

\begin{tabular}{|c|c|c|}
\hline Scientific name & Common English name & $\begin{array}{l}\text { Frequency } \\
(\mathrm{N})\end{array}$ \\
\hline $\begin{array}{l}\text { Family: Agamidae } \\
\text { 1. Calotes versicolor }\end{array}$ & Indian Garden Lizard & 3 \\
\hline $\begin{array}{l}\text { Family: Scincidae } \\
\text { 2. Mabuya multifasciata } \\
\text { 3. Lygosoma sp. }\end{array}$ & Many-lined Grass Skink & $\begin{array}{l}2 \\
1\end{array}$ \\
\hline $\begin{array}{l}\text { Family: Geckkonidae } \\
\text { 4. Gekko gecko }\end{array}$ & Tokay gecko & 1 \\
\hline $\begin{array}{l}\text { Family: Boidae } \\
\text { 5. Python molurus }\end{array}$ & Indian Rock Python & 3 \\
\hline $\begin{array}{l}\text { Family: Colubridae } \\
\text { 6. Amphiesma stolatum } \\
\text { 7. Boiga gokool } \\
\text { 8. Boiga quinquncinta } \\
\text { 9. Coelognathus helena } \\
\text { 10. Coelognathus radiatus } \\
\text { 11. Chrysopelea ornata } \\
\text { 12. Dendrelaphis pictus } \\
\text { 13. Dendralaphis sp. } \\
\text { 14. Enhydris enhydris } \\
\text { 15. Lycodon jara } \\
\text { 16. Ptyas mucosa } \\
\text { 17. Ptyas korros } \\
\text { 18. Xenochrophis piscator }\end{array}$ & $\begin{array}{l}\text { Buff-striped Keelback } \\
\text { Eastern Cat Snake } \\
\text { Assamese Cat Snake } \\
\text { Indian Trinket Snake } \\
\text { Copper-headed Trinket Snake } \\
\text { Ornate Flying snake } \\
\text { Common Bronzeback Tree Snake } \\
\text { Common Smooth Water Snake } \\
\text { Yellow-speckled Wolf Snake } \\
\text { Indian Rat Snake } \\
\text { Indo-Chinese Rat Snake } \\
\text { Checkered Keelback Water Snake }\end{array}$ & $\begin{array}{l}9 \\
14 \\
1 \\
8 \\
1 \\
2 \\
3 \\
1 \\
2 \\
1 \\
2 \\
1 \\
3\end{array}$ \\
\hline $\begin{array}{l}\text { Family: Elapidae } \\
\text { 19. Bungarus fasciatus } \\
\text { 20. Ophiophagus hannah }\end{array}$ & $\begin{array}{l}\text { Banded Krait } \\
\text { King Cobra }\end{array}$ & $\begin{array}{l}4 \\
2\end{array}$ \\
\hline $\begin{array}{l}\text { Family: Viperidae } \\
\text { 21. Trimeresurus albolabris }\end{array}$ & White-lipped Pit Viper & $\begin{array}{l}4 \\
\mathrm{~N}\end{array}=68$ \\
\hline
\end{tabular}

Table 2. List of reptiles found crossing or by the roadside

\begin{tabular}{lll}
\hline Scientific name & Common English name & $\begin{array}{c}\text { Frequency } \\
\text { (N) }\end{array}$ \\
\hline Calotes versicolor & Indian Garden Lizard & 3 \\
Mabuya multifasciata & Many-lined Grass Skink & 2 \\
Lygosoma sp. & & 1 \\
Cyrtodactylus khasiensis & Khasi Hills Bent Toed Gecko & 2 \\
Cosymbotus platyurus & Flat Tailed Gecko & 3 \\
Python molurus & Indian Rock Python & 1 \\
Amphiesma stolatum & Buff-striped Keelback & 3 \\
Boiga gokool & Eastern Cat Snake & 5 \\
Enhydris enhydris & Smooth Water Snake & 1 \\
Ptyas mucosa & Indian Rat Snake & 4 \\
Xenochrophis piscator & Checkered Keel Back Water Snake & 3 \\
Bungarus fasciatus & Banded Krait & 2 \\
Ophiophagus Hannah & King Cobra & 1 \\
Trimeresurus albolabris & White Lipped Pit Viper & 4 \\
& & $\mathrm{~N}=35$ \\
\hline
\end{tabular}

Large representation of nocturnal taxa (Boiga gokool, Bungarus fasciatus, Trimeresurus albolabris) and crepuscular taxa (Coelognathus helena helena) either dead or live on road presumably reflects their relative abundance across different habitat types of the study area (pers. obs.). However, day and night variation in traffic intensity particularly an increase in density of heavy vehicles during night hours coupled with visual constraints among drivers may also contribute towards high mortality among nocturnal taxa.

Again, water snakes, although abundant in the study area, are poorly represented on road. They might be avoiding roads and using water channels through road culverts, as more than 
roadkills they are found entangled in fish gill nets placed against water current under culverts. The barrier effect of the road is probably reflected by the family Gekkonidae, as their species are abundant in the forest, plantation as well as habitation areas near NH 37 (pers. obs.), but represented by a single individual (Gekko gecko) as roadkill.

This preliminary study provides baseline data on magnitude of reptile mortality near a protected area. The impacts of such loss on population remain unknown. It can be assumed that impacts are presumably species specific and detrimental for species with small and declining populations (Spellerberg, 1998).

\section{REFERENCES}

Ashley, E.P., \& J.T. Robinson (1996). Road mortality of amphibians, reptiles and other wildlife on the Long Point Causeway, Lake Erie, Ontario. Canadian Field-Naturalist 110: 403-412.

Chhangani, A.K. (2004). Mortality of wild animals in road accidents in Kumbhalgarh Wildlife Sanctuary, Rajasthan, India. Journal of the Bombay Natural Historty Society 101(1): 151-154.

Carr, L.W. \& L. Fahrig (2001). Effect of road traffic on two amphibian species of differing vagility. Conservation Biology 15: 1071-1078.

Develey, P.E. \& P.C. Stouffer (2001). Effects of roads on movements by understory birds in mixed species flocks in Central Amazonian Brazil. Conservation Biology 15: 1416-1422.

Demaynadier, P.G. \& M.L. Hunter, Jr. (2000). Road effects on amphibian movements in a forested landscape. Natural Areas Journal 20: 56-65.

Dodd, C.K. Jr., K.M. Enge \& J.N. Stuart (1989). Reptiles on highways in north-central Alabama, USA. Journal of Herpetology 23: 197-200.

Das, I. (1997). Checklist of the reptiles of India with English common names. Hamadryad 22: 32-45.

Das, I. (2002). A Photographic Guide to the Snakes and other Reptiles of India. New Holland Publisher (UK), Ltd., London. 144pp.

Das, I. (2003). Growth of knowledge on the Reptiles of India, with an introduction to systematics, taxonomy and nomenclature. Journal of the Bombay Natural History Society 100(2 \& 3): 446-501

Fahrig, L., J.H. Pedlar, S.E. Popoe, P.D. Taylor \& J.F. Wegner (1995). Effect of road traffic on amphibian density. Biological Conservation 73: 177-182.

Fitch, H.S. (1949). Road counts of snakes in western Louisiana. Herpetologica 5: 87-90.

Forman, R.T.T. \& L.E. Alexander (1998). Roads and their major ecological effects. Annual Review of Ecology and Systematics 29: 207231.

Goosem, M. (2001). Effects of tropical rainforest roads on small mammals: inhibition of crossing movements. Wildlife Research 28: 351364 .

Gokula, V. (1997). Impact of vehicular traffic on snakes in Mudumalai Wildlife Sanctuary. Cobra 27: 26.

Haxton, T. (2000). Road mortality of snapping turtles, Chelydra serpentina, in central Ontario during their nesting period. Canadian FieldNaturalist 114: 106-110.

Hels, T. \& E. Buchwald (2001). The effect of road kills on amphibian populations. Biological Conservation 99: 331-340.

Jayaram, K.C. (1974). Ecology and distribution of freshwater fishes, amphibians and reptiles, pp.517-580. In: Mani, M.S. (ed.). Ecology and Biogeography in India. Dr. W. Junk B.V. Publishers, The Hague.

Klauber, L.M. (1939). Studies of reptile life in the arid southwest Part 1: Night collecting on the desert with ecological statistics. Bulletin of the Zoological Society of San Diego 14: 7-64.

Mader, H.J. (1984). Animal habitat isolation by roads and agricultural fields. Biological Conservation 29: 81-96.

Oxley, D.J., M.B. Fenton \& G.R. Carmody (1974). The effects of roads on populations of small mammals. Journal of Applied Ecology 11: $51-59$.

Ortega, Y.K. \& D.E. Capen (1999). Effects of forest roads on habitat quality for ovenbirds in a forested landscape. Auk 116: 937-946.

Rosen, P.C. \& C.H. Lowe (1994). Highway mortality of snakes in the Sonoran desert of southern Arizona. Biological Conservation 68: 143-148. Reed, R.A., J. Johnson-Barnard \& W.L. Baker (1996). Contribution of roads to forest fragmentation in the Rocky Mountains. Conservation Biology 10: 1098-1106

Reh, W. \& A. Seitz (1990). The influence of landuse on the genetic structure of population of the common frog Rana temporaria. Biological conservation 54: 239-249.

Schleich, H.H. \& W. Kästle (Eds.) (2002). Amphibian and Reptiles of Nepal. Biology, Systematics, Field Guide. 1200pp + 377photos.

Shaffer, H.B. \& J.E. Juterbock (1994). Night driving, pp. 163-166. In: Heyer, W.R., M.A. Donnelly, R.W. McDiarmid, L.A.C. Hayek \& M.S. Foster (eds.). Measuring and Monitoring Biological Diversity: Standard Methods for Amphibians. Smithsonian Institution Press, Washington, D.C., U.S.A.

Smith, M.A. (1935). The Fauna of British India, Ceylon and Burma: Amphibia and Reptilia, Vol. II. Sauria. Taylor and Francis Ltd., London, 240pp.

Smith, M.A. (1943). The Fauna of British India, Ceylon and Burma, including. the whole of the Indo-Chinese region. Reptilia and Amphibia. Vol. III. Serpentes. Taylor and Francis, London, 583pp+i-xii+1map.

Spellerberg, I.F. (1998). Ecological effects of roads and traffic: a literature review. Global Ecological \& Biogeographical Letters 7: 317-333.

Turtle, S.L. (2000). Embryonic survivorship of the Spotted Salamander (Ambystoma maculatum) in roadside and woodland vernal pools in southeastern New Hampshire. Journal of Herpetology 34:60-67.

Vos, C.C., \& J.P. Chardon (1998). Effects of habitat fragmentation and road density on the distribution pattern of the Moor frog Rana arvalis. Journal of Applied Ecology 35: 44-56.

Vijaykumar, S.P., K. Vasudevan \& N.M. Ishwar (2001). Herpetofaunal mortality on roads in the Anamalai Hills, southern Western Ghats. Hamadryad 26(2): 253-260.

Zhao, E-M. \& K. Adler (1993). Herpetolohy of China. Society for Study of Amphibians and Reptiles, Contribution to Herpetology, 10, Oxford, Ohio, 522pp $+48 \mathrm{pls}+1$ folding map.

\section{ACKNOWLedgements}

We are thankful to Rufford Foundation U.K. for financial support. Thanks are also due to Assam Forest Department and Kaziranga Park Authorities for study permission. We are indebted to Center for Wildlife Rehabilitation and Conservation (Kaziranga National Park) of Wildlife Trust of India and Aaranyak for logistical support. Special thanks to Dharanidhar Boro, (Range officer, KNP) and N.K. Vasu (Director, KNP) for their constant support. Sincere thanks to Dr. P.C. Bhattacharjee of Department of Zoology, Gauhati University and Manoj Nair of Orissa Forest Department for comments on the manuscript.

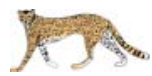

